\title{
Brassicaceae cover crops reduce Aphanomyces pea root rot without suppressing genetic potential of microbial nitrogen cycling
}

\author{
Shakhawat Hossain • Göran Bergkvist • Robert Glinwood • \\ Kerstin Berglund • Anna Mårtensson • Sara Hallin • Paula Persson
}

Received: 14 August 2014 / Accepted: 23 March 2015 /Published online: 2 April 2015

(C) The Author(s) 2015. This article is published with open access at Springerlink.com

\begin{abstract}
Aims Brassicaceae cover crops can be used to suppress soil-borne pathogens. The aim was to investigate the effect of different brassicas with different glucosinolate profiles on the development of Aphanomyces pea root rot in subsequent pea plants, and the genetic potential of free-living $\mathrm{N}_{2}$-fixing bacteria and ammonia oxidising bacteria (AOB) and archaea (AOA) performing key soil ecosystem services.

Methods The Brassicaceae species Brassica juncea and Sinapis alba and non-Brassicaceae species Secale cereale were grown for 11-weeks in Aphanomyces euteiches infested soil at low and high nitrogen $(\mathrm{N})$ fertiliser doses. After removing both shoots and roots of the cover crops, peas were grown as a bioassay to
\end{abstract}

Responsible Editor: John A. Kirkegaard.

S. Hossain $(\bowtie) \cdot$ G. Bergkvist $\cdot$ R. Glinwood $\cdot$ P. Persson Department of Crop Production Ecology, Swedish University of Agricultural Sciences, P.O. Box 7043, 75007 Uppsala, Sweden

e-mail: Shakhawat.Hossain@slu.se

K. Berglund · A. Mårtensson

Department of Soil and Environment, Swedish University of Agricultural Sciences, P.O. Box 7014, 75007 Uppsala, Sweden

S. Hallin

Department of Microbiology, Swedish University of Agricultural Sciences, P.O. Box 7025, 75007 Uppsala, Sweden evaluate Aphanomyces pea root rot development. Soil was sampled before harvesting the cover crops and at the end of the bioassay. Volatile compounds were collected in the root-soil environment before harvesting the Brassicaceae cover crops to determine the concentration of isothiocyanates. The abundance of genes involved in $\mathrm{N}_{2}$-fixing bacteria and ammonia oxidation in AOA and AOB were assessed.

Results Pea root rot disease severity was reduced in Brassicaceae grown soil at the high $\mathrm{N}$ fertiliser dose. This was associated with increased growth of the cover crops. The growth of Brassicaceae did not suppress the abundance of $\mathrm{N}$-cycling microbial communities, but rather increased the $\mathrm{AOB}$ at the end of the bioassay, most likely due to increased $\mathrm{N}$ availability. The disease suppressive effect was higher with $S$. alba than with $B$. juncea, and this coincided with a more diverse composition and higher concentration of aliphatic ITCs released from $S$. alba roots. Fewer nodules were formed after the Brassicaceae crops, especially Sinapis alba. Conclusions Brassicaceae cover crops, particularly S. alba, can be used to control soil-borne pathogens without major side effects on the genetic potential of beneficial soil microorganisms involved in $\mathrm{N}$ cycling. However, less nodule formation after brassicas indicates an effect on rhizobium activity.

Keywords Glucosinolates · Isothiocyanates · Aphanomyces euteiches · Brassicajuncea - Sinapis alba . Nitrogen fertlisation - Biofumigation 


\section{Introduction}

The persistent and globally distributed soil-borne pathogen Aphanomyces euteiches is an oomycete causing root rot in legumes, which is a severe problem in commercial pea (Pisum sativum L.) production (Papavizas and Ayres 1974; Gaulin et al. 2007; Persson 2008). Pea root rot is difficult to control without long intervals (6-8 years) between pea crops in the crop rotation. Biofumigation using plants from the Brassicaceae family is however of interest since many Brassicaceae species produce sulphur-containing secondary metabolites known as glucosinolates (GSLs) (Sang et al. 1984; Fahey et al. 2001; Hossain et al. 2012). When the GSLs are hydrolysed by the endogenous enzyme myrosinase, volatile isothiocyanates (ITCs), thiocyanates and water-soluble nitriles and epithionitriles are formed (Brown and Morra 1997; Kiddle et al. 2001). These products are toxic to soilborne pathogens (Kirkegaard et al. 2000; Potter et al. 2000; van Dam et al. 2009), but the suppressive effect depends on their chemical composition (Smolinska et al. 2003; Matthiessen and Shackleton 2005) and concentration (Angus et al. 1994; Sarwar et al. 1998; Hossain et al. 2014). For the pea root rot pathogen A. euteiches, in-vitro experiments have demonstrated reduced hyphal growth caused by volatiles from Brassica napus rapeseed meal (cv. Dwarf Essex) (Dandurand et al. 2000) and B. juncea (cv. Corron) shoot tissue (Hossain et al. 2014). Several field studies have shown that incorporation of B. napus or Sinapis alba (white mustard) plant tissue can reduce the incidence or development of root rot in subsequent pea crops (Chan and Close 1987; Muehlchen et al. 1990).

Most examples of biofumigation using brassicas are based on macerating the plants and incorporating them into the soil to achieve a sudden boost of toxic volatiles (Angus et al. 1994; Kirkegaard et al. 2000). Less is known about the effects of living and growing roots of brassicas on A. euteiches. A few studies have shown that intact Brassicaceae roots have an impact on fungal and bacterial communities (Rumberger and Marshner 2004; Bressan et al. 2009), and a negative effect on fungal spore germination (Schreiner and Koide 1993). Moreover, the amount of GSLs is usually higher in root than shoot tissue (Rosa 1997; van Dam et al. 2009). Borek et al. (1996) found a higher concentration of the myrosinase enzyme in rhizospheric soil of brassicas than in non-rhizospheric soil, and demonstrated that this enzyme actively hydrolysed GSLs.
Since the GSL hydrolysis products can suppress plant pathogens, there is concern over their toxic effect on beneficial organisms, including the rhizobium bacteria that are essential for pea root nodule formation for the fixation of atmospheric di-nitrogen gas $\left(\mathrm{N}_{2}\right)$ (Kirkegaard et al. 1999). Peas had fewer root nodules when Brassicaceae shoot tissues had been incorporated before sowing (Muehlchen et al. 1990), suggesting that GSL hydrolysis products inhibited bacteria essential for nodule formation, and the rhizobial community associated with living Brassicaceae roots was significantly influenced by changes in GSL root profiles (Bressan et al. 2009). Other soil microorganisms related to the cycling of $\mathrm{N}$ and their functions may be affected by GSL hydrolysis products. Bending and Lincoln (2000) found that synthetic ITCs inhibited nitrification activity and decreased growth of nitrifying bacteria, especially the ammonia oxidisers that perform the first step in the nitrification process. These organisms are known to be sensitive to a range of environmental disturbances and have therefore been used as indicator organisms for different types of soil perturbation (Wessén and Hallin 2011).

The aim of the current study was to compare two Brassicaceae species used as cover crops and to determine whether the hydrolysis products of GSLs from the intact growing roots reduce the development of Aphanomyces pea root rot in subsequent peas without affecting beneficial soil microorganisms. Our hypotheses were (i) that growing Brassicaceae crops reduce the development of Aphanomyces pea root rot in subsequent pea plants and (ii) reduce the growth of the soil $\mathrm{N}_{2}$-fixing and ammonia oxidising microorganisms, thereby decreasing the abundance of these organisms, and (iii) that the effect is greater the better the Brassicaceae plants grow. Further, we predict that the suppressive effects are linked to an increase in ITCs in the soil. This was tested by growing the Brassicaceae species $S$. alba and B. juncea, and the non-GSL containing plant Secale cereale in A. euteiches-infested field soil under two $\mathrm{N}$-fertilisation levels to determine the role of different growth intensities. The effect on the development of Aphanomyces pea root rot was evaluated using a bioassay with pea plants growing in the soil after removal of the cover crops. To evaluate potential negative side-effects on the soil microbial community, we investigated effects on the genetic potential of freeliving $\mathrm{N}_{2}$-fixing bacteria and ammonia oxidising bacteria $(\mathrm{AOB})$ and archaea (AOA) by quantifying genes of 
key enzymes involved in $\mathrm{N}_{2}$ fixation (nifH) and ammonia oxidation $(a m o A)$.

\section{Materials and methods}

Pathogen strain

Aphanomyces euteiches strain 5035:8B was used in all experiments (obtained from F. Heyman, Department of Forest Mycology and Plant Pathology, Swedish University of Agricultural Sciences, Uppsala, Sweden). The strain was maintained on corn meal agar (CMA) (Oxoid Ltd., UK) at $6{ }^{\circ} \mathrm{C}$ and was used for soil inoculation, using a method described by Schneider (1978) modified by Persson et al. (1999). In brief, A. euteiches was cultured in oat meal broth for 4 weeks, the mycelium mat of the culture was homogenised, and the oospore concentration quantified, mixed with talcum powder (VWR International) and dried. The dried inoculum material was sieved through a 1-mm mesh net and stored at $4{ }^{\circ} \mathrm{C}$ until use.

Soil sampling, experimental set-up, incidence of pea root rot and nodule formation

Soil was collected from an agricultural field in Giresta, Enköping, Sweden, sieved through a 6-mm mesh and stored at $4{ }^{\circ} \mathrm{C}$ at a soil moisture content of $21 \%$. The soil consisted of $46 \%$ clay, $48 \%$ silt, $2 \%$ sand and $4 \%$ organic matter, and the $\mathrm{pH}\left(\mathrm{H}_{2} \mathrm{O}\right)$ was 7.7. The absence of A. euteiches was confirmed by growing peas in freshly collected field soil for 4-weeks and assessing root rot development according to Parke et al. (1991).

At the start of the experiment, the soil was inoculated with the pathogen (450 oospores $\mathrm{g}^{-1}$ soil) and Brassica juncea (cv. Corron), Sinapis alba (cv. Architect) and Secale cereale (cv. Amilo) were sown separately in 8 experimental pots $(51)$. Half of the pots with a cover crop were fertilised with a high $\mathrm{N}$ dose $\left(336 \mathrm{~kg} \mathrm{~N} \mathrm{ha}^{-1}\right.$ soil) and half with a lower dose (168 $\mathrm{kg} \mathrm{N} \mathrm{ha}^{-1}$ soil). The high level was estimated to be enough for the fastest possible growth rate calculated from a previous greenhouse experiment and the lower level was half that amount. As controls, four replicates each of unfertilised soil and soil fertilised with the different $\mathrm{N}$ doses were used. All pots were incubated in the greenhouse (daynight period of $14: 10 \mathrm{~h}$ and temperature $19: 14 \pm 2{ }^{\circ} \mathrm{C}$ ) for 11 weeks. Soil moisture was adjusted daily by checking the weight loss of each pot and water was added with some surplus to avoid possible $\mathrm{NO}_{3}{ }^{-}$accumulation. A pre-prepared liquid nutrient solution $\left(1 \mathrm{M}\left(\mathrm{NH}_{4}\right)_{2} \mathrm{SO}_{4}\right)$ was used as fertiliser and applied six times with increasing doses for application 1 to 3 and decreasing doses for applications 4 to 6 . The nutrient application was made between 10 and 58 days after sowing the cover crops.

All cover crops were harvested when $S$. alba and $B$. juncea reached flowering stage 11 weeks after sowing, and the shoot tissue was discarded. Cover crop roots were removed from the soil by sieving, and the soil was returned to the original pots to be used in a bioassay. Water was added to the soil and the pots were left in the greenhouse for 2 days to allow any volatiles produced to evaporate, since we wanted to avoid any direct effect of ITCs in the bioassay. Eight pea seeds were then sown in each pot and incubated in the greenhouse for 4 weeks (day-night period $14: 10 \mathrm{~h}$ and temperature $24: 19 \pm 2{ }^{\circ} \mathrm{C}$ ). Soil moisture was adjusted daily by checking the weight loss of each pot and adding water accordingly to obtain optimal infection conditions. Germination of the pea seeds was estimated as percentage of emerged plants.

At the end of the 4-week bioassay, each pot was assigned a DSI (Disease Severity Index) value based on the mean pea root rot symptoms of the individual pea plants in that pot, according to Parke et al. (1991). Each individual plant was assigned one of five scores for disease severity: $0 \%=$ healthy plant; $25 \%=$ root slightly discoloured; $50 \%=$ root extensively discoloured but not shrunken; $75 \%=$ root extensively discoloured and shrunken; $100 \%=$ root partly or completely rotted or plant dead. In addition, pea root nodule formation was ranked based on the observation of all pea plants in each treatment. Each treatment was scored using a scale ranging from 1 to 5 with $1=$ low nodule formation and $5=$ high nodule formation.

One week before harvesting the cover crops, $2 \mathrm{~g}$ of soil was collected as five sub-samples taken randomly at a depth of $5 \mathrm{~cm}$ in each pot. The same procedure was used for the second soil sampling, which was carried out when harvesting the pea seedlings following the 4-week bioassay. The soil samples were stored at $-80^{\circ} \mathrm{C}$ prior to DNA extraction.

DNA extraction and quantification of amoA and nifH genes

DNA was extracted from $0.5 \mathrm{~g}$ soil sample using the FastDNA ${ }^{\circledR}$ Spin Kit for soil and the FastPrep ${ }^{\circledR}$ 
Instrument (MP Biomedicals, Irvine, CA, USA) according to the manufacturer's instructions. Real-time quantitative PCR of amoA genes coding for the ammonia monooxygenase enzyme required for $\mathrm{NH}_{3}$ oxidation was performed to estimate the genetic potential of ammonia oxidation by the ammonia oxidising bacteria (AOB) and ammonia oxidising archaea (AOA). To quantify the genetic potential of the free-living $\mathrm{N}_{2}$-fixing bacterial community, the gene nifH coding for the iron $(\mathrm{Fe})$ part of the nitrogenase enzyme that reduces $\mathrm{N}_{2}$ to $\mathrm{NH}_{4}{ }^{+}$was targeted. The primer pairs used were amoA1F (5'-GGGGTTTCTACTGGTGGT-3') and amoA2R (5'-CCCCTCKGSAAAGCCTTCTTC-3') (Rotthauwe et al. 1997) for bacterial amoA (AOB), crenAmoA23F (5'-ATGGTCTGGCTWAGACG-3') and crenAmoA616R (5'-GCCATCCATCTGTATGTC CA-3') (Tourna et al. 2008) for archaeal amoA (AOA) and Po1F (5'-TGCGAYCCSAARGCBGACTC-3') and Po1R (5'-ATBGCCATCATYTCRCCGGA-3') (Poly et al. 2001) for the nifH gene $\left(\mathrm{N}_{2}\right.$ fixing bacteria). The quantifications were performed in a total volume of $20 \mu \mathrm{l}$ using the DyNAmo ${ }^{\text {TM }}$ Flash SYBR ${ }^{\circledR}$ Green qPCR kit (Finnzymes, Vantaa, Finland), $0.50 \mu \mathrm{M}$ of each primer, $0.1 \% \mathrm{BSA}$ and $10 \mathrm{ng}$ soil DNA, using the CFX 96 тм Real-Time System (Bio-Rad Laboratories, Inc, Hercules, CA). Thermal cycling conditions consisted of an initial enzyme activation step at $95^{\circ} \mathrm{C}$ for $15 \mathrm{~min}$ followed by 35 cycles of $15 \mathrm{~s}$ at $95^{\circ} \mathrm{C}$, $30 \mathrm{~s}$ at $55^{\circ} \mathrm{C}, 30 \mathrm{~s}$ at $72{ }^{\circ} \mathrm{C}$, and a final step of $30 \mathrm{~s}$ at $80{ }^{\circ} \mathrm{C}$ at which fluorescence was acquired to avoid possible interactions with primer dimers and unspecific PCR products. The reactions were finished with a melting curve starting at $60^{\circ} \mathrm{C}$ with an increase of $0.5^{\circ} \mathrm{C}$ per $5 \mathrm{~s}$ up to $95^{\circ} \mathrm{C}$ to verify amplicon specificity in addition to checking the amplicons on $1 \%$ agarose gels. Two independent reactions were performed for each sample. Standard curves were obtained using serial dilutions $\left(r^{2}=1.00\right.$ for all curves) of linearised plasmids (pGEMT Easy; Promega, Madison WI USA) containing cloned fragments of the genes. Bacterial and archaeal amoA genes fragments were amplified from a soil sample prior to cloning, whereas the nifH fragments were amplified from Frankia alni ACN14a. In all three cases, the same primers as in the qPCR assays were used. The PCR runs had an efficiency of $88 \%$ (archaeal amoA) and $94 \%$ (bacterial amoA and nifH). Control samples without templates resulted in undetectable values. Inhibitory effects were tested by running each of the samples together with a known amount of a circular plasmid
(pGEM-T Easy) using the plasmid-specific primers T7 and $\mathrm{Sp} 6$, and the cycle thresholds $\left(\mathrm{C}_{\mathrm{t}}\right.$ values) obtained were not significantly different from those obtained when amplifying the plasmid in water.

Soil available nitrogen

To determine available ammonium $\left(\mathrm{NH}_{4}{ }^{+}\right)$and nitrate $\left(\mathrm{NO}_{3}{ }^{-}\right)$in the soil, $50 \mathrm{~g}$ of soil was collected from each experimental pot with the low $\mathrm{N}$ dose and the unfertilised control before (first) and after (second) the bioassay and stored at $-20{ }^{\circ} \mathrm{C}$. Soil available $\mathrm{N}_{-} \mathrm{NH}_{4}{ }^{+}$ and $\mathrm{N}_{-} \mathrm{NO}_{3}{ }^{-}$were extracted with $2 \mathrm{M} \mathrm{KCl}$ and determined colorimetrically by flow injection analysis using TRAACS 800 (Bran+Luebbe, Germany).

Analysis of isothiocyanates (ITCs) in the soil

Volatile compounds were collected from the growing roots of Brassicaceae plants after 11 weeks of growth before harvesting. A $10-\mathrm{mm}$ hole was made in the pots $5 \mathrm{~cm}$ below the soil surface. A glass tube was inserted in the hole, and into this was inserted a glass liner containing Tenax TA (50 mg 60/80 mesh, Supelco, Bellefont, USA). Air was pulled out through the liner/Tenax at $350 \mathrm{ml} \mathrm{min}^{-1}$. Volatile compounds in the root-soil environment were trapped for periods of $24 \mathrm{~h}$ at $24 \pm 2{ }^{\circ} \mathrm{C}$ under artificial light conditions. Collected volatiles were analysed by gas chromatography (GC) as described by Hossain et al. (2014), using decane (50 ng) as an internal standard for quantification. For tentative compound identification, volatile samples were collected as described above and analysed by coupled GC-mass spectrometry as described by Hossain et al. (2014). Compounds were identified by comparison against a commercially available library (National Institute of Standards and Technology, NIST 08, USA) and by comparison of mass spectra and retention indices with commercially available authentic standards (SigmaAldrich AB, Sweden). Standards were unavailable for two compounds, but the retention index (Kovats Index, $\mathrm{KI}$ ) of the substances could be matched with previously published KIs for the compounds on a HP-1 column.

Statistical analysis

The nifH and amo $A$ gene copy numbers, DSI values and the soil available $\mathrm{N}_{-} \mathrm{NH}_{4}{ }^{+}$and $\mathrm{N}_{-} \mathrm{NO}_{3}{ }^{-}$were log-10 transformed to equalise variation. The data obtained 
from the first soil sampling occasion (low $\mathrm{N}$ dose) was used to test the effects of the cover crops against a fertilised and unfertilised control on the variables $\mathrm{AOA}, \mathrm{AOB}$ and $\mathrm{N}_{2}$-fixing bacteria, before removing the cover crops. Data from both soil sampling occasions (low $\mathrm{N}$ dose) were used to test the effect of sampling time and cover crop treatment on soil mineral N, AOA, $\mathrm{AOB}$ and $\mathrm{N}_{2}$-fixing bacteria. Data from the second soil sampling occasion (both low and high $\mathrm{N}$ doses) were used to test the effect of $\mathrm{N}$ level and cover crop on AOA, AOB, $\mathrm{N}_{2}$-fixing bacteria and DSI at the end of the bioassay. Data were fitted in linear models and mean values of the variables in the different cover crop treatments were compared using the Honestly Significant Difference (HSD), Tukey's test with $P<0.05$ significance limit. The unfertilised control treatment was excluded when both $\mathrm{N}$ doses were included in the analyses.

To assess whether soils within the different treatments share microbiological properties after the pea growth assay, the variation in abundances of amoA genes from $\mathrm{AOA}$ and $\mathrm{AOB}$ and nifH from $\mathrm{N}_{2}$-fixing bacteria (nifH) in addition to DSI-values were compared using principal component analysis (PCA) with a correlation matrix. Difference between variations was examined by taking the sample scores of the ordination diagrams. Thus we focused on inter-sample distances on the significant axes determined by Monte Carlo permutation tests and the rank of each axis was determined by its eigenvalue $(\lambda)$.

All statistical analyses were performed using the " $\mathrm{R}$ " environment (version 2.15.2, The $\mathrm{R}$ Foundation, 2013). The PCA analysis was performed using the "FactoMineR" package.

\section{Results}

Development of Aphanomyces pea root rot

After growing S. alba cover crop for 11 weeks in Aphanomyces-infested soil at high nutrient dose, the pea bioassay revealed significantly lower pea root rot DSI in the Brassicaceae cover crop treatments compared to other treatments (Fig. 1). Growth of B. juncea at the high $\mathrm{N}$ level resulted in a lower DSI than in the control treatment, but the effect was not significantly different from that of $S$. cereale or the $\mathrm{N}$-fertilised control. No effects of cover crops were found at the low $\mathrm{N}$ dose. As hypothesized, the DSI-values were lower after the high $\mathrm{N}$ dose than after the low dose $(P<0.001)$ across all cover crop treatments, and there was a significant interaction $(P<0.002)$ between treatment and $\mathrm{N}$-fertilisation, indicating a larger effect of $\mathrm{N}$ with Brassicaceae cover crops, especially $S$. alba, than with $S$. cereale or the fertilised control.

Nodule formation

Eleven weeks of $S$. cereale growth enhanced nodule formation of subsequent peas compared to other treatments (Table 1). Growth of Brassicaceae cover crops, especially $S$. alba resulted in less nodule formation than in the other treatments. Moreover, there were fewer nodules on the pea roots after the high $\mathrm{N}$ dose than after the low $\mathrm{N}$ dose.

Abundance of genes from N-cycling microbial communities

Treatments with brassicas did not suppress the abundance of amoA or nifH genes from the ammoniaoxidising microorganisms or the free-living $\mathrm{N}_{2}$-fixing bacteria (Table 2 ). The gene copy numbers ranged from $5.0 \times 10^{7}$ to $1.0 \times 10^{8}$ for the AOA, $3.5 \times 10^{7}$ to $1.3 \times 10^{8}$ for the AOB and $4.1 \times 10^{8}$ to $8.1 \times 10^{8}$ for the $\mathrm{N}_{2}$-fixing bacteria per $g$ dry soil (Tables 2 and 3 ). Thus, if gene abundances are used as proxies for the size of the functional communities, the $\mathrm{N}_{2}$-fixing community was more abundant overall than the ammonia oxidisers, but the ranges of AOA and AOB gene copy numbers between treatments were greater than the range of nifH gene copies.

Based on the mean values, all three communities were more abundant in the treatments with brassicas than in the untreated control soil $(P=0.019)$ sampled both before and after the pea bioassay in the low $\mathrm{N}$-fertiliser treatments. Community size was also affected by sampling occasion, with the mean abundances being greater on the first soil sampling occasion $(P=0.001)$ than on the second occasion, after the pea bioassay. The abundances of the three genes reflecting the different microbial communities were greater in soils with the high $\mathrm{N}$-fertiliser dose than those with the low dose $(P=0.001)$ on the second sampling occasion. On the sampling before harvest (low $\mathrm{N}$ dose), the number of amoA genes from the AOA community was significantly higher $(P=0.017)$ in the fertilised control than in the 


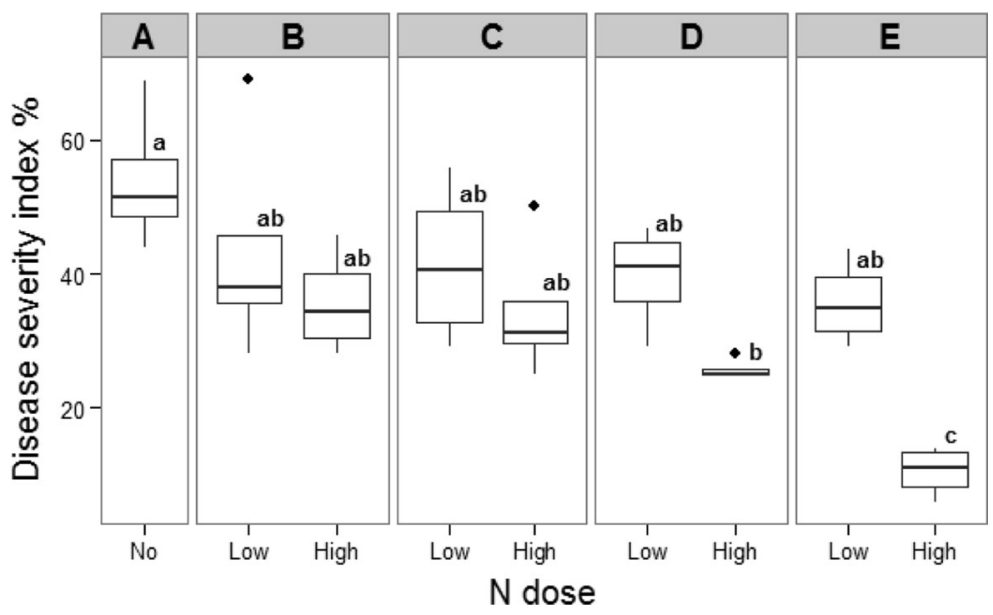

Fig. 1 Incidence of Aphanomyces pea root rot (disease severity index, DSI) on peas grown for 4 weeks in a bioassay after growing cover crops for 11 weeks at a low or high $\mathrm{N}$ dose in Aphanomyces euteiches infested soil, and removal of both shoots and roots. The treatments with crops were compared to fertilised or unfertilised treatments without cover crop: a unfertilised control, $\mathbf{b}$ fertilised control, c Secale cereale, d Brassica juncea and e Sinapis alba.

$S$. cereale treatment (Table 2). On the second sampling occasion, the number of nifH genes in the low N-dose regime was significantly higher $(P=0.030)$ in the $S$. cereale and $B$. juncea treatments than in the fertilised control. In soil samples collected after the 4-week pea bioassay from the high $\mathrm{N}$ fertiliser treatment, amoA genes from AOB were more abundant $(P<0.001)$ in all cover crop treatments and in the fertilised control compared to the untreated control soil.

Table 1 Pea root nodule formation rate based on an initial 11 weeks of growing a cover crop at a low or high $\mathrm{N}$ dose followed removal of cover crop and 4 weeks of pea growth. Different number indicate the rate of nodule formation in each treatment ( $1=$ low and $5=$ high)

\begin{tabular}{lll}
\hline \multirow{2}{*}{ Treatment } & \multicolumn{2}{l}{ Nodule formation } \\
\cline { 2 - 3 } & Low N dose & High N dose \\
\hline Unfertilised control $^{\mathrm{a}}$ & 3 & 3 \\
Fertilised control $^{\mathrm{b}}$ & 3 & 2 \\
Secale cereale $_{\text {Brassica juncea }}$ & 5 & 4 \\
Sinapis alba & 3 & 2 \\
& 2 & 1
\end{tabular}

${ }^{\text {a }}$ Aphanomyces-infested soil without cover crops and no N added, included in the observations of both Low and High $\mathrm{N}$ dose

${ }^{\mathrm{b}} 1 \mathrm{M}\left(\mathrm{NH}_{4}\right)_{2} \mathrm{SO}_{4}$ applied to Aphanomyces-infested soil without cover crops
The whiskers indicate minimum and maximum values and the points show single outliers. The ANOVA was made on 10logarithm transformed data and the figure shows the back transformed values. Different letters indicate significant differences between means within each $\mathrm{N}$ dose and in comparison with the control $(P<0.05$, Tukey's test, $\mathrm{n}=4)$

Associations between pea root rot DSI and N-cycling communities

There were relative differences among the N-cycling communities and the development of Aphanomyces pea root rot in the soils after the pea growth assay in the treatments according to the PCA (Fig. 2). The samples receiving a high $\mathrm{N}$ dose separated from the low $\mathrm{N}$ dose in the first two axes. In PC1, explaining $60.5 \%$ of the total variance, this was mainly driven by the increase of $\mathrm{N}$-cycling genes and the decrease in development of Aphanomyces pea root rot in the high $\mathrm{N}$ samples. Along the second axis, which explained $27.2 \%$ of the variance, the $S$. alba treatment with the high N-fertiliser dose DSI was clearly distinguished from the control treatment, and DSI was associated with $\mathrm{N}_{2}$-fixing nifH genes. The increased abundance of bacterial amo $A$ genes in the soils with the high $\mathrm{N}$-fertiliser dose was more associated to the treatments with plants, especially $S$. cereale (PC3, 8.6\% of the variance), indicating a positive effect of plants on this community.

Soil available $\mathrm{N}-\mathrm{NH}_{4}{ }^{+}$and $\mathrm{N}-\mathrm{NO}_{3}{ }^{-}$

The concentration of $\mathrm{N}^{-\mathrm{NO}^{-}}{ }_{3}$ at the first sampling was higher $(P=0.001)$ in fertilised and unfertilised control treatments than in treatments where cover crops were grown. However, the $\mathrm{N}$-concentrations in the control 
Table 2 Abundance (copies $\mathrm{g}^{-1}$ dry soil) of the amoA gene of ammonia-oxidising archaea (AOA) and ammonia-oxidising bacteria (AOB) and the $n i f H$ gene of free-living $\mathrm{N}_{2}$-fixing bacteria before (first) and after (second) a pea growth assay (based on an initial 11 weeks of growing a cover crop at a low or high $\mathrm{N}$ dose followed removal of cover crop and 4 weeks of pea growth)

\begin{tabular}{|c|c|c|c|c|c|c|c|c|c|}
\hline \multirow[t]{3}{*}{ Treatment } & \multicolumn{3}{|c|}{$A O A^{4}\left(10^{8}\right)$} & \multicolumn{3}{|c|}{$A O B^{4}\left(10^{8}\right)$} & \multicolumn{3}{|c|}{$\operatorname{nifH} H^{4}\left(10^{8}\right)$} \\
\hline & \multirow{2}{*}{$\begin{array}{l}\text { First } \\
\text { Low }\end{array}$} & \multicolumn{2}{|c|}{ Second } & \multirow{2}{*}{$\begin{array}{l}\text { First } \\
\text { Low }\end{array}$} & \multicolumn{2}{|c|}{ Second } & \multirow{2}{*}{$\begin{array}{l}\text { First } \\
\text { Low }\end{array}$} & \multicolumn{2}{|l|}{ Second } \\
\hline & & Low & High & & Low & High & & Low & High \\
\hline Unfertilised control $^{1}$ & $0.70^{\mathrm{ab}}$ & $0.60^{\mathrm{a}}$ & $0.60^{\mathrm{a}}$ & $0.57^{\mathrm{a}}$ & $0.42^{\mathrm{a}}$ & $0.42^{b}$ & $6.59^{\mathrm{a}}$ & $5.61^{\mathrm{ab}}$ & $5.61^{\mathrm{a}}$ \\
\hline 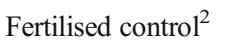 & $1.04^{\mathrm{a}}$ & $0.50^{\mathrm{a}}$ & $0.59^{\mathrm{a}}$ & $0.71^{\mathrm{a}}$ & $0.35^{\mathrm{a}}$ & $0.93^{\mathrm{a}}$ & $6.93^{\mathrm{a}}$ & $4.04^{b}$ & $4.84^{\mathrm{a}}$ \\
\hline Secale cereale & $0.58^{b}$ & $0.61^{\mathrm{a}}$ & $0.69^{\mathrm{a}}$ & $0.43^{\mathrm{a}}$ & $0.55^{\mathrm{a}}$ & $1.31^{\mathrm{a}}$ & $5.55^{\mathrm{a}}$ & $6.12^{\mathrm{a}}$ & $6.10^{\mathrm{a}}$ \\
\hline Brassica juncea & $0.92^{\mathrm{ab}}$ & $0.69^{\mathrm{a}}$ & $0.88^{\mathrm{a}}$ & $0.75^{\mathrm{a}}$ & $0.57^{\mathrm{a}}$ & $1.05^{\mathrm{a}}$ & $8.04^{\mathrm{a}}$ & $5.98^{\mathrm{a}}$ & $6.79^{\mathrm{a}}$ \\
\hline Sinapis alba & $0.78^{\mathrm{ab}}$ & $0.61^{\mathrm{a}}$ & $0.68^{\mathrm{a}}$ & $0.82^{\mathrm{a}}$ & $0.60^{\mathrm{a}}$ & $1.19^{\mathrm{a}}$ & $7.21^{\mathrm{a}}$ & $5.32^{\mathrm{ab}}$ & $5.53^{\mathrm{a}}$ \\
\hline Standard error ${ }^{3}$ & 0.097 & 0.010 & 0.008 & 0.018 & 0.012 & 0.009 & 0.101 & 0.077 & 0.089 \\
\hline p-value & 0.017 & 0.404 & 0.064 & 0.229 & 0.061 & $<0.001$ & 0.288 & 0.030 & 0.247 \\
\hline
\end{tabular}

Different letters indicate significant differences between means within $\mathrm{N}$ dose and in comparison with the control $(P<0.05$, Tukey's test, $n=4)$

${ }^{a}$ Aphanomyces-infested soil without cover crops and no $\mathrm{N}$ added, included in the analyses of both Low and High $\mathrm{N}$ dose

b $1 \mathrm{M}\left(\mathrm{NH}_{4}\right)_{2} \mathrm{SO}_{4}$ applied to Aphanomyces-infested soil without cover crops

${ }^{\mathrm{c}}$ Standard error of transformed means

${ }^{\mathrm{d}}$ The ANOVA was made on 10-logarithm transformed data and the figure shows the back transformed values

treatments declined during the bioassay with pea growth, and no significant difference remained after the bioassay. The concentration of $\mathrm{N}^{-\mathrm{NH}_{4}}{ }^{+}$in the soil

Table 3 Effects of 11 weeks of cover crop growth at a low $\mathrm{N}$ dose on the soil N-NH${ }_{4}^{+}$and $\mathrm{N}_{-} \mathrm{NO}_{3}{ }^{-}$content (mg kg ${ }^{-1}$ dry soil) based on soil samples collected before (first) and after (second) a 4 week pea growth bioassay at a low $\mathrm{N}$ dose

\begin{tabular}{|c|c|c|c|c|}
\hline \multirow[t]{2}{*}{ Treatment } & \multicolumn{2}{|c|}{$\mathrm{N}-\mathrm{NH}_{4}^{+4}$} & \multicolumn{2}{|c|}{$\mathrm{N}-\mathrm{NO}_{3}^{-4}$} \\
\hline & First & Second & First & Second \\
\hline Unfertilised control $^{1}$ & $2.60^{\mathrm{c}}$ & $2.91^{\mathrm{c}}$ & $9.04^{b}$ & $1.26^{\mathrm{a}}$ \\
\hline Fertilised control $^{2}$ & $2.63^{\mathrm{bc}}$ & $3.14^{\mathrm{bc}}$ & $69.79^{\mathrm{a}}$ & $2.25^{\mathrm{a}}$ \\
\hline Secale cereale & $4.86^{\mathrm{a}}$ & $4.25^{\mathrm{a}}$ & $0.62^{\mathrm{c}}$ & $1.38^{\mathrm{a}}$ \\
\hline Brassica juncea & $3.50^{\mathrm{abc}}$ & $3.58^{\mathrm{b}}$ & $0.97^{\mathrm{c}}$ & $2.08^{\mathrm{a}}$ \\
\hline Sinapis alba & $4.22^{\mathrm{ab}}$ & $3.44^{\mathrm{b}}$ & $1.18^{\mathrm{c}}$ & $2.51^{\mathrm{a}}$ \\
\hline Standard error ${ }^{3}$ & 0.21 & 0.07 & 0.54 & 0.53 \\
\hline p-value & 0.005 & 0.001 & 0.001 & 0.500 \\
\hline
\end{tabular}

Different letters indicate significant differences $(P<0.05$, Tukey's test, $n=4$ )

${ }^{\text {a }}$ Aphanomyces- infested soil without cover crops and added $\mathrm{N}$

${ }^{\mathrm{b}} 1 \mathrm{M}\left(\mathrm{NH}_{4}\right)_{2} \mathrm{SO}_{4}$ applied to Aphanomyces-infested soil without cover crops

${ }^{\mathrm{c}}$ Standard error of transformed means

${ }^{\mathrm{d}}$ The ANOVA was made on 10-logarithm transformed data and the figure shows the back transformed values was higher $(P=0.005)$ in treatments with cover crops than in the controls on both sampling occasions, and was particularly high in the $S$. cereale treatment.

ITCs in the soil-root environment

The quantity of ITC volatiles in the root-soil environment of growing $B$. juncea plants was higher than with S. alba (Table 4). The dominant ITC in the B. juncea soil was aromatic 2-phenylethyl, which was detected in amounts more than ten times higher than in the $S$. alba soil. Nevertheless, the quantity of aliphatic ITCs was higher and the composition more diverse in the $S$. alba soil than with $B$. juncea.

\section{Discussion}

In this study, where the two Brassicaceae species B. juncea and S. alba were grown in A. euteiches infested soil, ITCs were present in the root-soil environment of both brassicas after 11 weeks of growth, but it was primarily $S$. alba that showed inhibitory effects on root rot severity in subsequently cultivated pea plants. There was an interaction with $\mathrm{N}$ fertilisation, but the fertilised control treatment without cover crop did not significantly affect the disease severity index, in neither the low nor the 


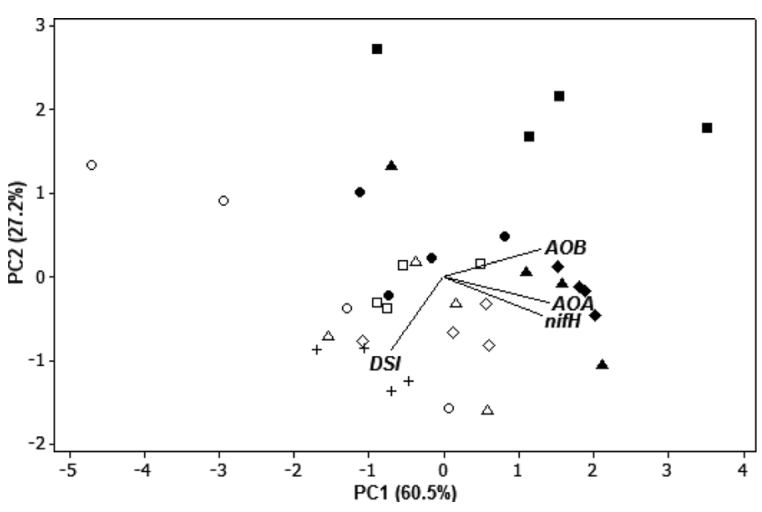

Fig. 2 Principal component (PC) analysis showing the associations between abundances of amo $A$ and nifH genes from ammoniaoxidising and free-living $\mathrm{N}_{2}$-fixing microbial communities, and the development of Aphanomyces pea root (disease severity index). The microbial parameters were determined after the pea growth assay, which followed an initial 11 weeks of growing a cover crop at a high (filled) or low (unfilled) $\mathrm{N}$ dose. Treatments: Brassica juncea (diamonds), Sinapis alba (squares), Secale cereale (triangles) fertilised control (circles) and unfertilised control (plus). Abbreviations: DSI, disease severity index; AOA, ammoniaoxidising archaea; $\mathrm{AOB}$, ammonia-oxidising bacteria; nifH, gene for nitrogenase in $\mathrm{N}_{2}$-fixing bacteria. The total variance explained is $87.5 \%$ and the proportion for each PC is indicated

high $\mathrm{N}$ dose regimes. Thus, the results support the idea that living roots of certain brassicas can be used to supress $A$. euteiches pea root rot by releasing either ITCs directly or other water soluble products that are rapidly hydrolysed from GSLs in the root-soil environment. It is known that the suppressive effect depends on the ITC composition and concentration (Angus et al. 1994; Matthiessen and Shackleton 2005) and on the exposure time of the organism (Hossain et al. 2014). Our results suggest that only the type and amount of ITCs originating from $S$. alba intact roots were important for reducing the development of pea root rot by suppressing A. euteiches. Several studies have shown that aliphatic ITCs exhibit a stronger toxic effect than the aromatic ITCs (Sarwar et al. 1998; Smolinska et al. 2003; Matthiessen and Shackleton 2005; Hossain et al. 2014). Nevertheless, the aromatic 2-phenylethyl ITC detected in the $B$. juncea treatment is known to have toxic effects on several organisms, including mycelium growth of A. euteiches as shown by in-vitro tests using synthetic 2 phenylethyl dissolved in a fungal growth medium (Smith and Kirkegaard 2002). If the A. euteiches oospores are less sensitive than the mycelium of this pathogen, this could explain why the higher concentrations of 2-phenylethyl in the root-zone of $B$. juncea compared to S. alba, did not affect the development of pea root rot in the present study. Matthiessen and Shackleton (2005) showed that the biological activity of ITCs is significantly affected by the presence of soil. They observed that although the aromatic ITCs can exert a strong effect, their activity declines rapidly compared to the activity of aliphatic ITCs. This could explain why the relatively high concentration of aromatic compared to aliphatic ITCs in the $B$. juncea root rhizosphere did not strongly affect A. euteiches in our study. Since aliphatic ITCs exhibit a stronger toxic effect than the aromatic ITCs, and were present in higher concentrations and with greater diversity in $S$. alba than in B. juncea, this could explain the suppressive effect registered for the $S$. alba treatment. Further, a non-volatile ionic thiocyanate $\left(\mathrm{SCN}^{\top}\right)$ is normally produced from the sinalbin GSL known to be present in $S$. alba roots, or from the unstable sinalbin hydrolysed ITC 4-hydroxybenzyl (Gmelin and Virtanen 1960; Kawakishi and Muramatsu 1966). Since SCN is toxic to various microorganisms (Brown and Morra 1997), this may also have affected the pathogen. The greater suppression of the disease observed at the high $\mathrm{N}$ dose could be explained by enhanced cover crop growth rather than a direct $\mathrm{N}$-effect as there was no impact of higher $\mathrm{N}$ in control soil. Accordingly, increased $\mathrm{N}$ fertilisation would result in a larger root volume and potentially more GSLs being produced.

Disease suppression by the brassicas could also be explained by indirect effects, and multiple mechanisms of action, other than activity of GSL hydrolysis products, have been suggested. Since Brassicaceae amendments have been shown to alter soil microbial communities several authors have proposed possible disease suppressive effects (Omirou et al. 2011; Wang et al. 2014; Mowlick et al. 2013). As in the present study, Rumberger and Marshner (2004) showed ITC release from living roots of canola and suggested that root pathogens may be directly or indirectly negatively affected by ITCs via observed changes in rhizosphere microbial community composition. Mazzola et al. (2012) speculated that the ITCs from rapeseed meal stimulated soil fungi, which resulted in a significant reduction in disease development caused by the plant pathogenic oomycete Pythium. However, Cohen et al. (2005) recorded high concentrations of nitric oxide (NO) after rapeseed meal amendments, which could indicate a role for bacterial-derived NO in disease suppression. In the present study we cannot exclude changes in the microbial community in any of the treatments, but potential indirect effects caused by altered 
Table 4 Volatile compounds released from growing roots of Brassica juncea (cv. Corron) and Sinapis alba (cv. Architect) collected in soil during $24 \mathrm{~h}$
${ }^{\mathrm{a}}$ mass spectrum and KI match with NIST and authentic standard

${ }^{\mathrm{b}}$ mass spectrum match in NIST and KI concurs with $\mathrm{KI}$, published by Valette et al. 2006

${ }^{\mathrm{c}} \mathrm{SE}$ (Standard Error)

dnd (not detected)

\begin{tabular}{|c|c|c|c|c|c|}
\hline \multirow[t]{2}{*}{ Category } & \multirow[t]{2}{*}{ ITC } & \multicolumn{2}{|c|}{ Brassica juncea } & \multicolumn{2}{|c|}{ Sinapis alba } \\
\hline & & $\mu \mathrm{g} 24 \mathrm{~h}^{\mathrm{a}}$ & $\mathrm{SE}^{\mathrm{c}}$ & $\mu \mathrm{g} 24 \mathrm{~h}^{\mathrm{a}}$ & $\mathrm{SE}^{\mathrm{c}}$ \\
\hline \multirow[t]{5}{*}{ Aliphatic } & Allyl $^{\mathrm{a}}$ & 15.00 & 5.20 & $\mathrm{nd}^{\mathrm{d}}$ & \\
\hline & Heptyl $^{\mathrm{a}}$ & nd & & 7.36 & 3.07 \\
\hline & 3-Butenyl ${ }^{\mathrm{b}}$ & nd & & 21.10 & 9.13 \\
\hline & 3-Methylhexyl ${ }^{\mathrm{b}}$ & nd & & 9.96 & 5.79 \\
\hline & 4-Methylpentyl ${ }^{\mathrm{a}}$ & nd & & 2.39 & 0.42 \\
\hline Total aliphatic & & 15.00 & & 40.78 & \\
\hline \multirow[t]{2}{*}{ Aromatic } & Benzyl $^{\mathrm{a}}$ & nd & & 27.30 & 14.70 \\
\hline & 2-Phenylethyl ${ }^{\mathrm{a}}$ & 486.80 & 162.10 & 30.50 & 13.80 \\
\hline Total aromatic & & 486.80 & & 57.80 & \\
\hline Other volatile & Dimethyl Trisulphide ${ }^{\mathrm{a}}$ & 43.70 & 29.50 & nd & \\
\hline Total volatile & & 545.50 & & 98.60 & \\
\hline
\end{tabular}

communities were only manifested in terms of decrease disease severity in the soil with S. alba.

Formation of root nodules was most effective when peas were grown after Secale cereale which coincided with the lowest level of $\mathrm{NO}_{3}{ }^{-}$after 11 weeks of $S$. cereale growth in the soil. According to Brockwell et al. (1989), a high level of soil $\mathrm{N}$ diminishes both rhizobium colonisation and nodulation in soybeans. Thus, the low level of $\mathrm{NO}_{3}{ }^{-}$observed in our study likely influenced the rhizobium bacteria to form more nodules in the pea roots. The formation of pea root nodules was lower after Brassicaceae cover crops, especially Sinapis alba. The higher amounts of aliphatic ITCs generated by S. alba than Brassica juncea might have suppressed the activity of the rhizobia. In agreement, Muehlchen et al. (1990) showed that incorporated Brassicaceae tissues in soil significantly reduced the formation of pea root nodules and they suggested that hydrolysed products of GSLs reduce the activity of rhizobium bacteria.

Contrary to our prediction, the brassicas did not have any suppressive effect on the abundance of the $\mathrm{N}_{2}$ fixing and ammonia-oxidising microbial communities. Wang et al. (2014) showed a direct lowering and persistent lower abundance of ammonia-oxidising bacteria in rapeseed meal treatments, whereas Cohen et al. (2005) reported an increased abundance. Our results suggest that the genetic potential of the N-cycling organisms is not strongly affected by biofumigation efforts using brassicas, which is in line with Omirou et al. (2011) who did not find any effect on the ammonia-oxidising bacterial community in biofumigation treatments with broccoli residues. Other studies have shown that root nodule formation and growth of rhizobia communities were affected by soil incorporated Brassicaceae tissues and living roots of brassicas (Muehlchen et al. 1990; Bressan et al. 2009). Moreover, synthetic ITCs as well as GSLs hydrolysed products from incorporated Brassicaceae tissues can inhibit nitrification (Bending and Lincoln 2000; Brown and Morra 2009). This may be influenced by soil types. Brown and Morra (2009) used a silt-loam and Bending and Lincoln (2000) a sandy- and a clay-loam both with markedly lower clay content than in the present study. The clay soil might have a better buffering capacity. The lack of a negative effect in the current study may be due to differing effects of the various types of ITCs brassicas can produce. Therefore we conclude that the genetic potential of $\mathrm{N}_{2}$ fixing and ammonia-oxidising communities were less sensitive to the isothiocyanates originating from GSLs in the root-soil environment of the studied Brassicaceae cover crops than was the A. euteiches oospores' ability to cause root rot in subsequent peas. Although we cannot exclude the possibility that $\mathrm{N}_{2}$-fixation and ammonia-oxidation activities were affected by the GSL hydrolysis products, the effect was not strong enough to affect growth to such an extent that it decreased the genetic potential for these important soil functions. Instead, a positive response of the bacterial ammonia oxidisers was seen in all treatments compared to the control in the soils receiving high $\mathrm{N}$-fertilisation. This suggests that the time was sufficient to allow detectable changes in the microbial communities at the 
DNA level and that growth occurred. The clear separation of $S$. alba from the control treatment along the second axis of the PCA (Fig. 2) can largely be explained by the low DSI in peas grown after $S$. alba (high $\mathrm{N}$ dose), but also by $\mathrm{N}$-cycling communities being relatively more associated to $S$. alba than the control. This indicates that the cover crops have multiple effects on the soil microbial community and that the effect of the cover crops on the subsequent crop is complex.

High concentrations of $\mathrm{NO}_{3}{ }^{-}$were detected in the fertilised control without cover crop plants prior to the pea growth bioassay (Table 3). This indicates that ammonia oxidisers in the soil were active and oxidised the ammonium fertiliser to nitrate during the experiment. After the bioassay, the $\mathrm{NO}_{3}{ }^{-}$-concentration in the $\mathrm{N}$-fertilised control was reduced to similar levels as in the other treatments. The pea plants probably consumed some $\mathrm{NO}_{3}{ }^{-}$and some could have been denitrified and lost, but most of the $\mathrm{NO}_{3}{ }^{-}$probably leached, since the peas were irrigated daily with some surplus to enhance disease development, equalize water supply among treatments and avoid drought. Changes in the relative abundances of the bacterial amo $A$ genes were associated with $\mathrm{N}$-fertilisation, which confirms previous findings that $\mathrm{N}$-fertilisers affect the nitrifying community (Zhang et al. 2010; Wessén et al. 2011; Levičnik-Höfferle et al. 2012). The significant increase in AOB but not AOA in the high $\mathrm{N}$ dose treatments suggests that the AOB reacted more strongly to high $\mathrm{N}$ availability than their archaeal counterparts. Ammonia-oxidising bacteria often dominate in nutrient-rich environments (Wells et al. 2009; Di et al. 2010), and it has been suggested that lownutrient conditions create a potential niche for AOA (Erguder et al. 2009). This is supported by the very low $K_{\mathrm{m}}$-values for ammonia recorded for the marine archaeon Nirosopumilis maritimus and an archaeal soil enrichment when compared with a range of AOB species (Prosser and Nicol 2012 and references therein). Nevertheless, considering the high diversity of terrestrial AOA, there could be organisms with lower affinities. Niche differentiation in relation to $\mathrm{N}$ is not fully understood and tolerance of high ammonia concentrations and the source of ammonia as well as other soil factors may also be important, since no single soil factor seem to discriminate between AOA and AOB (Prosser and Nicol 2012). Interestingly, the size of the AOA community was smallest in the $S$. cereale treatment when sampled before harvesting the cover crop. The $S$. cereale crop could have been more competitive when it comes to N-uptake since it produced a larger root volume than the Brassicaceae cover crops, according to observations at the time of cover crop harvest. Another explanation could be that the growing roots of $S$. cereale inhibited the AOA community by releasing root exudates (Kruidhof et al. 2008). As reviewed by Subbarao et al. (2012), forage grass species and species within cereal crops like Sorghum have shown biological nitrification inhibition.

The relative increases in the abundances of functional genes from the microbial $\mathrm{N}$-cycling communities were negatively correlated with the development of pea root rot, and were associated with the high $\mathrm{N}$ dose regime. Thus, the overall positive effect of $\mathrm{N}$ addition on the $\mathrm{N}$ cycling community could explain part of the decrease in DSI. Soil microbial biomass and microbial activity are generally positively correlated with the suppression of soil borne diseases such as Pythium damping-off of maize and bean root rots (Darby 2003). Matthiessen and Kirkegaard (2006) also suggested that organic N in soil promotes the growth of soil organisms and indirectly affects soil-borne pathogens. Nevertheless, the abundance of nif $H$ genes was high in the unfertilised control treatment showing the most severe development of pea root rot. Since $\mathrm{N}_{2}$-fixing rhizobium bacteria (Maxwell et al. 1989) and zoospores of Aphanomyces spp. (Tahara et al. 2001) are both attracted by the gradient of flavonoids released from pea roots, the incidence of Aphanomyces pea root rot and the abundance of the $\mathrm{N}_{2}$-fixing community may be positively correlated. It has been suggested that the mineral salts have a direct suppressive effect on Aphanomyces by increasing the osmotic pressure in A. euteiches cells and reducing their activity (Lewis 1973). Another suggested mechanism by which Aphanomyces infection can be reduced by nutrients is that the nutrients make the pea root tissues more woody in character and difficult for the pathogen to infect (Smith and Walker 1941). In addition, $\mathrm{N}$ can have many effects on the soil microbial community that are not investigated here, but that could affect Aphanomyces infection.

We conclude that 11 weeks growth of Brassicaceae cover crops until flowering did not decrease the genetic potential of the soil $\mathrm{N}_{2}$-fixing and ammonia-oxidising communities, despite the fact that the brassicas did suppress Aphanomyces pea root rot. This suggests that growth of Brassicaceae cover crops does not negatively influence the presence of key N-cycling organisms in the soil. However, further in-depth studies may reveal 
negative long-term effects on the activity of these organisms, or on other soil organisms with important ecosystem functions.

Acknowledgments The project was funded by the research programme SLU EkoForsk at the Swedish University of Agricultural Sciences. We thank Maria Hellman for technical assistance.

Open Access This article is distributed under the terms of the Creative Commons Attribution 4.0 International License (http:// creativecommons.org/licenses/by/4.0/), which permits unrestricted use, distribution, and reproduction in any medium, provided you give appropriate credit to the original author(s) and the source, provide a link to the Creative Commons license, and indicate if changes were made.

\section{References}

Angus JF, Gardner PA, Kirkegaard JA, Desmarchelier JM (1994) Biofumigation: Isothiocyanates released from Brassica roots inhibit growth of the take-all fungus. Plant Soil 162:107-112

Bending GD, Lincoln SD (2000) Inhibition of soil nitrifying bacteria communities and their activities by glucosinolate hydrolysis products. Soil Biol Biochem 32:1261-1269

Borek V, Morra MJ, McCaffrey JP (1996) Myrosinase activity in soil extracts. Soil Sci Soc Am J 60:1792-1797

Bressan M, Roncato M-A, Bellvert F, Comte G, Haichar FH, Achouak W, Berge O (2009) Exogenous glucosinolate produced by Arabidopsis thaliana has an impact on microbes in the rhizosphere and plant roots. ISME J 3:1243-1257

Brockwell J, Gault RR, Morthorpe LJ, Peoples MB, Turner GL, Bergersen FJ (1989) Effects of soil nitrogen status and rate of inoculation on the establishment of populations of Bradyrhizobium japonicum and on the nodulation of soybeans. Aust J Agric Res 40:753-762

Brown PD, Morra MJ (1997) Control of soil-borne plant pests using glucosinolate-containing plants. Adv Agron 61:167231

Brown PD, Morra MJ (2009) Brassicaceae tissues as inhibitors of nitrification in soil. J Agric Food Chem 57:7706-7711

Chan MKY, Close RC (1987) Aphanomyces root rot of peas 3 Control by the use of cruciferous amendments. N Z J Agric Res 30:225-233

Cohen MF, Yamasaki H, Mazzola M (2005) Brassica napus seed meal soil amendment modifies microbial community structure, nitric oxide production and incidence of Rhizoctonia root rot. Soil Biol Biochem 37:1215-1227

Dandurand LM, Mosher RD, Knudsen GR (2000) Combined effects of Brassica napus seed meal and Trichoderma harzianum on two soilborne plant pathogens. Can J Microbiol 46:1051-1057

Darby HM (2003) Soil Organic Matter Management and Root Health. Dissertation, Oregon State University

Di HJ, Cameron KC, Shen J-P, Winefield CS, Callaghan MO, Bowatte S, He J-Z (2010) Ammonia-oxidising bacteria and archaea grow under contrasting soil nitrogen conditions. FEMS Microbiol Ecol 72:386-394
Erguder TH, Boon N, Wittebolle L, Marzorati M, Verstraete W (2009) Environmental factors shaping the ecological niches of ammonia-oxidizing archaea. FEMS Microbial Rev 33: $855-869$

Fahey JW, Zalcmann AT, Talalay P (2001) The chemical diversity and distribution of glucosinolates and isothiocyanates among plants. Phytochemistry 56:5-51

Gaulin E, Jacquet C, Bottin A, Dumas B (2007) Root rot disease of legumes caused by Aphanomyces euteiches. Mol Plant Pathol 8:539-548

Gmelin R, Virtanen AI (1960) The enzymic formation of thiocyanate (SCN-) form a precursor(s) in Brassica species. Acta Chem Scand 14:507-509

Hossain S, Bergkvist G, Berglund K, Mårtensson A, Persson P (2012) Aphanomyces pea root rot disease and control with special reference to impact of Brassicaceae cover crops. Acta Agric Scand Sect B 62:477-487

Hossain S, Bergkvist G, Berglund K, Glinwood R, Kabouw P, Mårtensson A, Persson P (2014) Concentration and time dependent effects of isothiocyanates produced from Brassicaceae shoot tissues on the pea root rot pathogen Aphanomyces euteiches. J Agric Food Chem 62:4584-4591

Kawakishi S, Muramatsu K (1966) Studies on the decomposition of sinalbin. Agric Biol Chem 30:688-692

Kiddle G, Bennett RN, Botting NP, Davidson NE, Robertson AAB, Wallsgrove RM (2001) High-performance liquid chromatographic separation of natural and synthetic desulphoglucosinolates and their chemical validation by UV NMR and chemical ionisation-MS methods. Phytochem Anal 12:226-242

Kirkegaard JA, Sarwar M, Wong PTW, Mead A, Howe G, Newell M (2000) Field studies on the biofumigation of take-all by Brassica break crops. Aust J Agric Res 51:445-456

Kirkegaard JA, Mele PM, Howe GN (1999) Enhanced accumulation of mineral-N following canola. Aust J Exp Agric 39: 587-593

Kruidhof HM, Bastiaans L, Kropff MJ (2008) Ecological weed management by cover cropping: effects on weed growth in autumn and weed establishment in spring. Weed Res 48:492502

Levičnik-Höfferle S, Nicol GW, Ausec L, Mandić-Mulec I, Prosser JI (2012) Stimulation of thaumarchaeal ammonia oxidation by ammonia derived from organic nitrogen but not added inorganic nitrogen. FEMS Microbiol Ecol 80:114-123

Lewis JA (1973) Effect of mineral salts on Aphanomyces euteiches and Aphanomyces root rot of peas. Phytopathology 63:989 993

Matthiessen JN, Kirkegaard JA (2006) Biofumigation and enhanced biodegradation: Opportunity and challenge in soilborne pest and disease management. Crit Rev Plant Sci 25: 235-265

Matthiessen JN, Shackleton MA (2005) Biofumigation: environmental impacts on the biological activity of diverse pure and plant-derived isothiocyanates. Pest Manag Sci 61:1043-1051

Maxwell CA, Hartwig UA, Joseph CM, Phillips DA (1989) A chalcone and two related flavonoids released from alfalfa roots induce nod genes of Rhizobium meliloti. Plant Physiol 91:842-847

Mazzola M, Reardon CL, Brownb J (2012) Initial Pythium species composition and Brassicaceae seed meal type influence 
extent of Pythium-induced plant growth suppression in soil. Soil Biol Biochem 48:20-27

Mowlick S, Yasukawa H, Inoue T, Takehara T, Kaku N, Ueki K, Ueki A (2013) Suppression of spinach wilt disease by biological soil disinfestation incorporated with Brassica juncea plants in association with chnges in soil bacterial communities. Crop Prot 54:185-193

Muehlchen AM, Rand RE, Parke JL (1990) Evaluation of green manures for controlling Aphanomyces root rot of peas. Plant Dis 74:651-654

Omirou M, Rousidou C, Bekris F, Papadopoulou KK, MenkissglouSpiroudi U, Ehaliotis C, Karpouzas DG (2011) The impact of biofumigation and chemical fumigation methods on the structure and function of the soil microbial community. Microbial Ecol 61:201-213

Papavizas GC, Ayres WA (1974) Aphanomyces species and their root diseases in pea and sugarbeet: a review. Techn Bull 1485: US Dept of Agric, Washington DC

Parke JL, Rand RE, Joy AE, King EB (1991) Biological control of pythium damping-off and aphanomyces root rot of peas by application of Pseudomonas cepacia or P. Fluorescens to seed. Plant Dis 75:987-992

Persson L (2008) Ärtrotröta och Rotbrand i odlingssystemförsöken 2001-2005. In: Gissén C and Larsson I (Eds) Miljömedvetna och uthålliga odlingsformer 1987-2005, pp 125-134, Rapport 2008:1 Swedish University of Agricultural Sciences, LTJ Faculty Alnarp Sweden (In Swedish)

Persson L, Larsson-Wikström M, Gerhardson B (1999) Assessment of soil suppressiveness to Aphanomyces root rot of pea. Plant Dis 83:1108-1112

Poly F, Ranjard L, Nazaret S, Gourbière F, Monrozier LJ (2001) Comparison of nifH gene pools in soils and soil microenvironments with contrasting properties. Appl Environ Microbiol 67:2255-2262

Potter MJ, Vanstone VA, Davies KA, Rathjen AJ (2000) Breeding to increase the concentration of 2-phenylethyl glucosinolate in the roots of Brassica napus. J Chem Ecol 26:1811-1820

Prosser JI, Nicol GW (2012) Archaeal and bacterial ammoniaoxidisers in soil: the quest for niche specialisation and differentiation. Trends Microbiol 20:523-531

Rosa EAS (1997) Daily variation in glucosinolate concentrations in the leaves and roots of cabbage seedlings in two constant temperature regimes. J Sci Food Agric 73:364-368

Rotthauwe JH, Witzel KP, Liesack W (1997) The ammonia monooxygenase structural gene amo $A$ as a functional marker: Molecular fine-scale analysis of natural ammoniaoxidizing populations. Appl Environ Microbiol 63:47044712

Rumberger A, Marshner P (2004) 2-Phenylethylisothiocyanate concentration and bacterial community composition in the rhizosphere of field-grown canola. Funct Plant Biol 31:623631

Sang JP, Minchinton P, Johnstone P, Truscott RJW (1984) Glucosinolate profiles in the seed root and leaf tissue of cabbage mustard rapeseed radish and swede. Can J Plant Sci 64:77-93

Sarwar M, Kirkegaard JA, Wong PTW, Desmarchelier JM (1998) Biofumigation potential of brassicas: In-vitro toxicity of isothiocyanates to soil-borne fungal pathogens. Plant Soil 201:103-112

Schneider CL (1978) Use of oospore inoculum of Aphanomyces cochloides to initiate blackroot disease in sugar beet seedlings. J Am Soc Sugar Beet 20:55-62

Schreiner PR, Koide RT (1993) Mustards mustard oils and mycorrhizas. New Phytol 123:107-113

Smith BJ, Kirkegaard JA (2002) In vitro inhibition of soil microorganisms by 2-phenylethyl isothiocyanate. Plant Pathol 51: 585-593

Smith PG, Walker JC (1941) Certain environmental and nutritional factors affecting Aphanomyces root of garden pea. J Agric Res 63:1-20

Smolinska U, Morra MJ, Knudsen GR, James RL (2003) Isothiocyanates produced by Brassica species as inhibitors of Fusarium oxysporum. Plant Dis 87:407-412

Subbarao GV, Sahrawat KL, Nakahara K, Ishikawa T, Kishii M, Rao IM, Hash CT, George TS, Rao PS, Nardi P, Bonnett D, Berry W, Suenaga K, Lata JC (2012) Biological nitrification inhibition - a novel strategy to regulate nitrification in agricultural systems. Adv Agron 114:249-302

Tahara S, Ohkawa K, Takayama T, Ogawa Y (2001) The third naturally occurring attractant toward zoospores of phytopathogenic Aphanomyces cochlioides from the Spinacia oleracea host plant. Biosci Biotech Biochem 65:1755-1760

Tourna M, Freitag TE, Nicol GW, Prosser JI (2008) Growth activity and temperature responses of ammonia-oxidizing archaea and bacteria in soil microcosms. Environ Microbiol 10:357-1364

Valette L, Fernandez X, Poulain S, Lizzani-Cuvelier L, Loiseau AM (2006) Chemical composition of the volatile extracts from Brassica oleracea L var botrytis 'Romanesco' cauliflower seeds. Flavour Frag J 21:107-110

van Dam NM, Tytgat TOG, Kirkegaard JA (2009) Root and shoot glucosinolates: a comparison of their diversity function and interactions in natural and managed ecosystems. Phytochem Rev 8:171-186

Wang Q, Ma Y, Wang G, Gu Z, Sun D, An X, Chang Z (2014) Integration of biofumigation with antagonistic microorganism can control Phytophthora blight of pepper plants by regulating soil bacterial community straucture. Eur J Soil Biol 61:58-67

Wells GF, Park HD, Yeung CH, Eggleston B, Francis CA, Criddle CS (2009) Ammonia-oxidizing communities in a highly aerated full-scale activated sludge bioreactor: betaproteobacterial dynamics and low relative abundance of Crenarchaea. Environ Microbiol 11:2310-2328

Wessén E, Hallin S (2011) Abundance of archaeal and bacterial ammonia oxidizers-Possible bioindicator for soil monitoring. Ecol Indic 11:1696-1698

Wessén E, Söderström M, Stenberg M, Bru D, Hellman M, Welsh A, Thomsen F, Klemedtson L, Philippot L, Hallin S (2011) Spatial distribution of ammonia-oxidizing bacteria and archaea across a 44-hectare farm related to ecosystem functioning. ISME J 5:1213-1225

Zhang L, Offrea PR, Heb J, Verhammea DT, Nicola GW, Prossera JI (2010) Autotrophic ammonia oxidation by soil thaumarchaea. PNAS 107:17240-17245 